\title{
Role of thiols, $\mathrm{pH}$ and cathepsin $\mathrm{D}$ in the lysosomal catabolism of serum
}

\section{albumin}

\author{
John L. MEGO \\ Department of Biology, and the Interdisciplinary Biochemistry Program, University of Alabama, University, \\ $A L$ 35486, U.S.A.
}

(Received 22 August 1983/Accepted 25 November 1983)

\begin{abstract}
Attempts were made to assess the role of thiols and to determine the cathepsins involved in the degradation of serum albumin in mouse liver and kidney lysosomes. Unlike cysteine or $\beta$-mercaptoethanol, reduced glutathione (GSH) did not stimulate the degradation of formaldehyde-treated albumin in liver lysosomes, suggesting that the tripeptide did not penetrate the membrane. However, GSH was a much more effective stimulant of proteolysis in kidney lysosomes than was cysteine at low concentrations, and the effect was saturable at $1-2 \mathrm{~mm}$ concentrations. Thiols did not stimulate proteolysis in lysosomes when the disulphide bonds of albumin were reduced and alkylated, suggesting that the stimulatory effects were solely due to disulphide-bond reduction in protein substrates. Results obtained with thiols and iodoacetamide suggested that albumins denatured by disulphide-bond reduction and alkylation, disulphide-bond reduction without alkylation, or by treatment with $8 \mathrm{M}$ urea, were all degraded primarily by cathepsin D in lysosomes, but formaldehydedenatured albumin was attacked by thiol proteinases. These findings correlated well with studies on the degradation of these proteins by rat liver lysosome (tritosome) extracts. Studies with the proteinase inhibitors leupeptin and pepstatin and the stimulatory effects of thiols in these extracts suggested that formaldehyde-denatured albumin was degraded primarily by the thiol proteinases, but that native albumin or albumins denatured by disulphide-bond reduction or by treatment with $8 \mathrm{M}$-urea were attacked by cathepsin D. Denaturation of serum albumin by any of the methods used caused a shift in the pH optimum of albumin catabolism by tritosome extracts or by purified cathepsin D from approx. 3-4 to 5-6. These results were discussed in terms of a possible mechanism for the catabolic aspect of serum albumin turnover.
\end{abstract}

Formaldehyde-treated serum albumin labelled with [ $\left.{ }^{125} \mathrm{I}\right]$ - or $\left[{ }^{131} \mathrm{I}\right]$-iodide has been used as a substrate in studies on intralysosomal proteolysis (Davies et al., 1971; Bertini et al., 1972; Mego, 1973; Nilsson \& Berg, 1977; Marzella \& Glaumann, 1980). A thiol compound such as cysteine or $\beta$-mercaptoethanol is required for maximum rates of degradation of this protein in lysosomes (Mego \& McQueen, 1965; Mego, 1973). Similar observations have been made in studies on the degradation of thyroglobulin in thyroid lysosomes (Peake et al., 1967; Pisarev \& Dumont, 1975; Fouchier et al., $1983 b$ ). Suggestions have been made that the function of thiols in the facilitation of intralysosomal proteolysis may be to reduce substrate disulphides

Abbreviation used: GSH, reduced glutathione.
(Wollman, 1969; Pisarev \& Dumont, 1975; Van Herle et al., 1979), and some evidence for this has been obtained (Libenson \& Jena, 1963, 1964; Kooistra et al., 1982). This function of GSH and perhaps other cellular thiols appears not to be enzymically mediated (Griffiths \& Lloyd, 1979; Kooistra et al., 1982). However, lysosomes contain several thiol proteinases that require a thiol compound such as GSH for activity (Barrett et al., 1977; Kirschke et al., 1976, 1977), and the stimulatory effects of thiols on intralysosomal proteolysis may be to keep active-site sulphur of these proteinases in the reduced state.

The accumulation of cystine in cystinosis (Schulman et al., 1969), which has been shown to arise from proteins undergoing degradation in lysosomes (Thoene et al., 1977), suggests that protein 
disulphides are not reduced. The defect in cystinosis has been shown to be due to an impaired exodus of cystine (Gahl et al., 1982; Jonas et al., 1982; Steinherz et al., 1982) rather than entry of a disulphide-reducing agent or faulty reduction of disulphide bonds. Thus the function of thiols as stimulators of intralysosomal proteolysis has not been resolved. Indeed, another function of thiols such as GSH may be to stabilize lysosome membranes.

Serum albumin is a linear polypeptide of about 65000-70000 Da containing 17 disulphide bridges (Putnam, 1965; Brown, 1974, 1975). The protein is rapidly degraded in lysosomes in both the liver and kidneys after intravenous injections into mice, but only if it is denatured in some manner such as treatment with formaldehyde (Mego, 1971). Undenatured bovine serum albumin is a better substrate for the thiol cathepsins than for cathepsin D at pH5, but carboxymethylation of thiol groups causes the protein to become more susceptible to attack by cathepsin D (Huisman et al., 1974). The pH optimum of cathepsin D is about 3 (Woessner, 1973; Ferenčik \& Štefanivič, 1974; Cunningham \& Tang, 1976; Ducastaing et al., 1976). Thus it would appear that this proteinase should not be involved in intralysosomal proteolysis to any great extent, since intralysosomal $\mathrm{pH}$ is known to be approx. 5 .

The present studies were undertaken to assess the role of thiol compounds, particularly GSH, in the intralysosomal degradation of serum albumin. For example, attempts were made to determine if thiols such as GSH or cysteine function solely to facilitate proteolysis in lysosomes by reducing the disulphide bonds of protein substrates, or if they may have other functions. Efforts were also made to determine the specific cathepsins involved in albumin degradation within lysosomes and, in particular, if cathepsin $D$ is involved to any significant extent.

\section{Experimental}

\section{Proteins}

Crystalline bovine serum albumin (Sigma Chemical Co., St. Louis, MO, U.S.A.) was labelled with carrier-free $\mathrm{Na}^{125} \mathrm{I}$ and treated with formaldehyde as previously described (Mego, 1971, 1973). Disulphides of ${ }^{125}$ I-labelled albumin (non-formaldehyde-treated) were reduced and alkylated by treating $60 \mathrm{mg}$ of protein with 10 -fold molar excess (with respect to disulphides) of dithiothreitol in $8 \mathrm{M}$-urea and $50 \mathrm{mM}$-Tris/acetate buffer, pH 8, for $4 \mathrm{~h}$. A 2-fold excess (with respect to dithiothreitol) of iodoacetate was then added, and the mixture was left at room temperature for $30 \mathrm{~min}$. The same procedure was used in the preparation of partially alkylated albumin, except that dithiothreitol only sufficient to reduce half the disulphide bonds of albumin was used. Reduced nonalkylated albumin was prepared with 10-fold excess of dithiothreitol in $8 \mathrm{M}$-urea, but the protein was not alkylated with iodoacetate. Urea-treated albumin was prepared similarly, but dithiothreitol or iodoacetate was not added. The proteins were dialysed against $1 \mathrm{mM}-\mathrm{NH}_{3}$ and then against distilled water or $0.85 \%(\mathrm{w} / \mathrm{v}) \mathrm{NaCl}$. All preparations, including formaldehyde-treated albumin, were completely soluble at $\mathrm{pH} 5$ or above, but precipitated at $\mathrm{pH} 3.3-4.8$ in Tris/acetate or Tris/citrate buffers. Untreated labelled albumin did not precipitate at any $\mathrm{pH}$ above 2.6. Labelled proteins were stored frozen until used. Specific radioactivities of proteins for injection into mice were approx. $10^{7}$ c.p.m./mg. Specific radioactivities of preparations used as substrates for lysosomal proteinases were about $5 \times 10^{4}-10 \times 10^{4}$ c.p.m./ mg.

\section{Enzyme preparation and assay}

Rat liver lysosomal enzymes were prepared by centrifugation of osmotically disrupted tritosomes. Tritosomes were prepared by the method of Leighton et al. (1968) as described by Dean (1977). After removal from sucrose gradients, the tritosomes were dialysed for $4 \mathrm{~h}$ against distilled water at $4^{\circ} \mathrm{C}$. Centrifugation at $48000 \mathrm{~g}$ for $30 \mathrm{~min}$ sedimented lysosome membranes, and the clear supernatant was stored frozen until used. These extracts were used within 4 weeks of preparation.

Tritosome extracts were assayed at $37^{\circ} \mathrm{C}$ in $0.25 \mathrm{ml}$ volumes containing $0.1 \mathrm{M}$-Tris/citrate buffer, $0.5 \mathrm{mg}$ of labelled protein and other additions as described in the text. Tris/citrate buffers were prepared by adding Tris to a solution of citric acid to the desired $\mathrm{pH}$ at room temperature and then adjusting the volume to $0.5 \mathrm{M}$-citrate. The actual $\mathrm{pH}$ of these buffers was measured at $37^{\circ} \mathrm{C}$ at the dilution used in proteinase assays. Proteolysis was assayed by removal of samples (at least 20000 c.p.m.; background approx. 150 c.p.m.) to $3.5 \mathrm{ml}$ counting vials containing $0.05 \mathrm{ml}$ of $20 \%(\mathrm{w} / \mathrm{v})$ bovine serum albumin as coprecipitant, followed by $3 \mathrm{ml}$ of $10 \%$ (w/v) trichloroacetic acid. These were counted for radioactivity in a gamma counter $(80 \%$ efficiency with ${ }^{125} \mathrm{I}$ ) with automatic sample changer. They were then chilled, centrifuged, and the acid-soluble fraction was decanted into fresh counting vials and counted for radioactivity to determine the fraction of protein hydrolysed. Reaction mixtures were incubated for periods sufficient to obtain approx. $50 \%$ hydrolysis $(25-75 \%)$ in the controls without inhibitors but with thiols present. The quantity of enzyme added and the incubation times depended on the protein substrate assayed. A $2 \mathrm{~h}$ incubation period and $15 \mu \mathrm{g}$ of tritosome-extract protein were 
sufficient to obtain approx. $50 \%$ hydrolysis of all albumins except formaldehyde-treated albumin. This substrate required an incubation period of $4 \mathrm{~h}$ and approx. $50 \mu \mathrm{g}$ of extract protein. Protein was assayed as described by Lowry et al. (1951), except that $0.1 \mathrm{ml}$ of $10 \%(\mathrm{w} / \mathrm{v})$ deoxycholate, $\mathrm{pH} 11$, was added to the samples before addition of the reagents to prevent precipitation of Triton WR1339, which was present in the preparations. Appropriate bovine serum albumin standards were run with each assay.

Cathepsin D (bovine spleen; approx. 10 units/ $\mathrm{mg}$ of protein) was obtained from Sigma. The preparation was dissolved in water and dialysed against 2 litres of cold distilled water for $6 \mathrm{~h}$ before use. Assay of this enzyme was performed similarly to the procedure described above for tritosome extracts.

The inhibitors leupeptin hemisulphate and pepstatin A (Sigma) were added at concentrations of $20 \mu \mathrm{M}$ and $12 \mu \mathrm{M}$ respectively. A plot of degree of inhibition of hydrolysis of a variety of albumin substrates by tritosome extracts against concentration of inhibitor showed that $10-40 \mu \mathrm{M}$-leupeptin and 3-30 $\mu$ M-pepstatin inhibited to the same extent respectively. Leupeptin was dissolved in water at a concentration of $100 \mu \mathrm{g} / \mathrm{ml}$ and kept frozen until used. Pepstatin was dissolved in $50 \%$ (v/v) methanol at the same concentration. Equal volumes of $50 \%$ methanol were added to controls in studies with pepstatin.

\section{Intralysosomal proteolysis}

Assays of proteolysis in mouse liver and kidney lysosomes were performed essentially as previously described (Mego, 1971, 1973). Mice were injected into the tail vein with $0.1 \mathrm{ml}\left(1 \mathrm{mg}\right.$, approx. $1 \times 10^{7}$ $5 \times 10^{7}$ c.p.m.) of labelled protein, and the animals were killed $30 \mathrm{~min}$ later. Organs were removed and homogenized in cold $0.25 \mathrm{M}$-sucrose. Particulate fractions sedimenting between $500 \mathrm{~g}$ and $30000 \mathrm{~g}$ containing lysosomes filled with ${ }^{125} \mathrm{I}$-labelled albumin (approx. $10^{5}-10^{6}$ c.p.m.) were thoroughly suspended with a pipette in $5 \mathrm{ml}$ of cold $0.25 \mathrm{M}$ sucrose. Portions $(0.5 \mathrm{ml})$ of these suspensions were added to $4.5 \mathrm{ml}$ of preincubated $\left(37^{\circ} \mathrm{C}\right)$ reaction mixtures, consisting of $0.25 \mathrm{M}$-sucrose, $5 \mathrm{mM}$ $\mathrm{MgCl}_{2}, 50 \mathrm{~mm}$-Tris/acetate buffer, $\mathrm{pH} 7.2$, and other additions as described in the text. The $\mathrm{pH}$ of GSH was adjusted to that of the incubation mixture and all thiols were added immediately before the particulate suspensions. Samples were removed at zero time and at intervals (usually $1 \mathrm{~h}$ ), and added to counting vials, followed by $10 \%(\mathrm{w} / \mathrm{v})$ trichloroacetic acid. These samples were counted for radioactivity, chilled and centrifuged to pack the undegraded protein. Supernatant fractions were decanted into fresh vials and counted to determine the percentage of the total radioactivity converted into acid-soluble form. This procedure has been demonstrated to be a valid measure of intralysosomal proteolysis (Mego, 1973).

\section{Chemicals and reagents}

Thiols, iodoacetate, iodoacetamide, leupeptin, pepstatin, Tris, sucrose, citrate and certain other chemicals were purchased from Sigma. Triton WR-1339 was purchased from Ruger Chemical Co., Irvington, NJ, U.S.A. [ ${ }^{125}$ I] Iodide (carrierfree) was obtained from ICN, Irvine, CA, U.S.A. All other chemicals were reagent grade or the purest available from laboratory-chemical distributors.

\section{Animals}

Adult albino mice and Sprague-Dawley rats were obtained from Charles River Breeding Laboratories, Wilmington, MA, U.S.A. These animals were maintained in the animal facilities of this institution until used.

\section{Results}

\section{Effects of thiols on intralysosomal proteolysis}

Fig. 1 shows the stimulatory effects of cysteine and GSH concentrations on proteolysis of formaldehyde-treated albumin in mouse kidney and liver lysosomes. Both thiols were effective in kidney lysosomes, but GSH had no effect on proteolysis in lysosomes from liver. GSH, a much larger molecule, was significantly more effective than cysteine at low concentrations in kidney lysosomes, and the effect was saturable at a concentration of $2 \mathrm{~mm}$. Cysteine and GSH were equally effective when tested in a particulate-free tritosome extract with formaldehyde-treated albumin as substrate, and both were saturable at $10-20 \mathrm{~mm}$ concentrations (J. L. Mego, unpublished work).

The stimulatory effect of GSH on proteolysis in kidney lysosomes may have been due to something other than reduction of substrate disulphide bonds. For example, the thiol may have acted on the membrane, perhaps by stabilizing lysosomal integrity. However, GSH had a negligible effect on proteolysis if the intralysosomal substrate was serum albumin without disulphide bonds, e.g. reducedalkylated albumin. Six experiments with this protein resulted in three stimulatory effects $(9-35 \%)$ and three inhibitions (7-10\%) with $2 \mathrm{~mm}-\mathrm{GSH}$, resulting in a mean stimulation of $6 \pm 7 \%$ (see Table 2). Thus, if the stimulatory effect of GSH were on something other than substrate disulphide bonds, the effect should have been independent of the substrate.

Lack of a stimulatory effect by GSH on proteolysis in liver lysosomes indicated that the tripeptide 


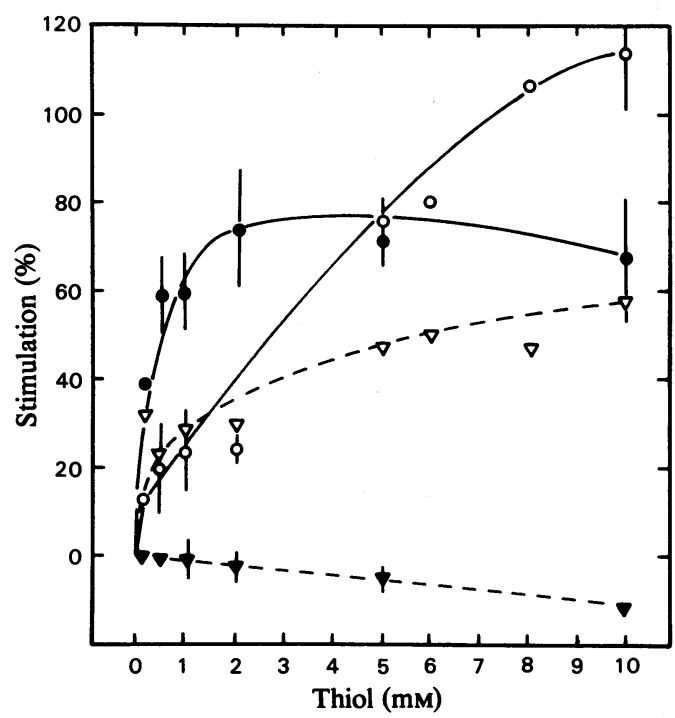

Fig. 1. Stimulatory effects of cysteine and GSH on proteolysis of formaldehyde-treated serum albumin in mouse kidney and liver lysosomes

Subcellular particulate material sedimented from liver and kidney homogenates containing ${ }^{125} \mathrm{I}$ labelled albumin-filled lysosomes was incubated in media containing various concentrations of thiol, $50 \mathrm{mM}$-Tris/acetate buffer, $\mathrm{pH} 7.2,5 \mathrm{mM}-\mathrm{MgCl}_{2}$ and $0.25 \mathrm{M}$-sucrose. Trichloroacetic acid-soluble radioactivity was measured at zero time and after $60 \mathrm{~min}$ incubation at $37^{\circ} \mathrm{C}$. Symbols: $, \nabla, \mathrm{GSH} ; \mathrm{O}, \nabla$, cysteine; --_-, liver; _- , kidney. All points are means of two to ten experiments, and those with vertical bars (S.E.M.) represent at least four experiments.

did not penetrate the membrane. Attempts were made to determine if a cofactor or some special conditions were required for the transport of GSH into liver lysosomes. These efforts included the additions of cell-free liver extracts, reduced or oxidized nicotinamide nucleotides, ascorbate, ATP, bivalent cations and various combinations of these at pH 7-8. GSH had no effect in the presence or absence of these additions. With the exception of ATP, which stimulated proteolysis as previously described (Mego et al., 1972), the additions above also produced no effects. The tripeptide therefore appears to be important in facilitating proteolysis in kidney lysosomes, but not in lysosomes from liver.

\section{Effects of thiols on the activity of cathepsin D}

Kooistra et al. (1982) showed that GSH stimulates cathepsin D activity with albumin or insulin as substrate. This stimulatory effect was attributed to a non-enzymic reduction of substrate disulphide bonds. However, Kooistra et al. (1982) did not ex-

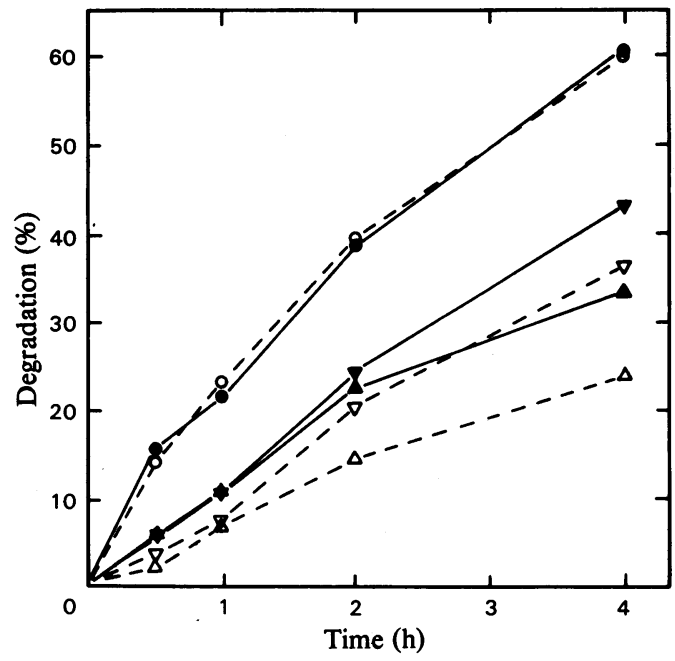

Fig. 2. Effects of GSH on the degradation of untreated, partially reduced-alkylated and completely reduced-alkylated albumin by cathepsin $D$

Reaction mixtures containing $0.5 \mathrm{mg}$ of labelled albumin, $0.1 \mathrm{M}$-Tris/citrate buffer, $\mathrm{pH} 4$, and 0.2 unit $(16 \mu \mathrm{g})$ of cathepsin $\mathrm{D}$ in volumes of $0.25 \mathrm{ml}$ were incubated with $(-; \boldsymbol{O}, \boldsymbol{\nabla}, \Delta)$ and without (----; $\mathrm{O}, \nabla, \Delta) \mathrm{GSH}$. Trichloroacetic acid-soluble radioactivity was measured at the times indicated and calculated as a percentage of the total. Bovine serum albumin was used to co-precipitate undegraded labelled protein. Each point represents the mean of two to four experiments. At $4 \mathrm{~h}$, catabolism of completely reduced albumin $(0,0)$ was stimulated by a mean of $1.4 \pm 1.1 \%(n=4)$, that of untreated albumin $(\Delta, \Delta)$, by $37 \pm 8 \%(n=3)$, and that of partially reduced albumin $(\nabla, \nabla)$ by $21 \pm 4 \%(n=3)$.

clude the possibility that cathepsin $\mathrm{D}$ may be stabilized by GSH or that the thiol may have some allosteric modulating function. If GSH facilitates proteolysis by reducing disulphide bonds, then the thiol should have no effect if the substrate has no disulphides. Fig. 2 shows that GSH stimulated the degradation of albumin, but not if disulphides were completely reduced and alkylated. An intermediate degree of stimulation was obtained if albumin disulphides were only partially reduced and alkylated.

Effects of $p H$ on albumin degradation by lysosomal cathepsins

Fig. 3 shows the effect of $\mathrm{pH}$ on degradation of undenatured and formaldehyde-treated albumin by a rat liver tritosome extract. Denaturation caused a shift in the pH optimum from 3.5-4.3 to 5-5.4. Fig. 4 shows $\mathrm{pH} /$ activity curves of completely or partially reduced-alkylated, urea-treated and reduced but not alkylated albumins. The $\mathrm{pH}$ 


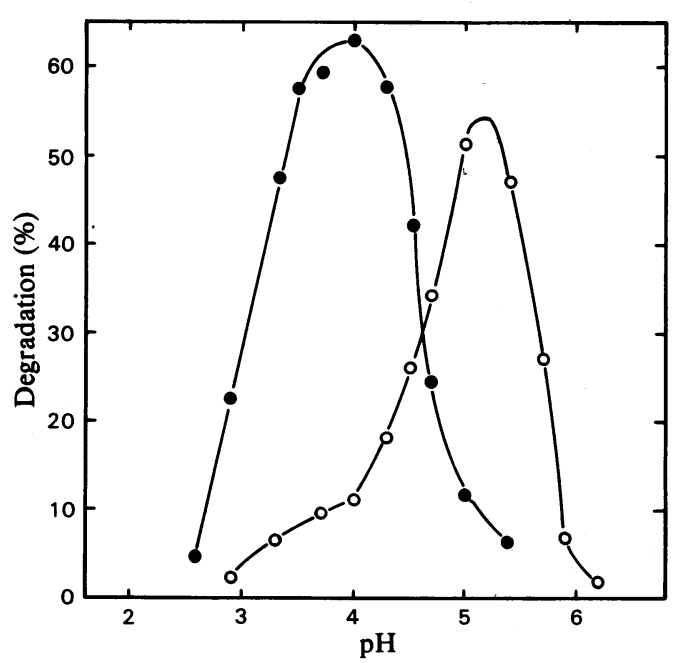

Fig. 3. Effects of $\mathrm{pH}$ on the degradation of formaldehydetreated and untreated bovine serum albumin by rat liver tritosome extract

Reaction mixtures contained $1 \mathrm{mg}$ of ${ }^{125} \mathrm{I}$-labelled protein, $0.1 \mathrm{M}$-Tris/citrate buffer, $10 \mathrm{~mm}$-cysteine and $11 \mu \mathrm{g}$ (for untreated albumin) or $55 \mu \mathrm{g}$ (for formaldehyde-treated albumin) of tritosome-extract protein in volumes of $0.5 \mathrm{ml}$. Samples were removed at zero time and after incubation at $37^{\circ} \mathrm{C}$ for $4 \mathrm{~h}$ (formaldehyde-treated albumin) or $1 \mathrm{~h}$ (untreated albumin) and assayed for trichloroacetic acid-soluble radioactivity, by using $1 \mathrm{mg}$ of serum albumin as coprecipitant. Untreated albumin; $O$, formaldehyde-treated albumin.

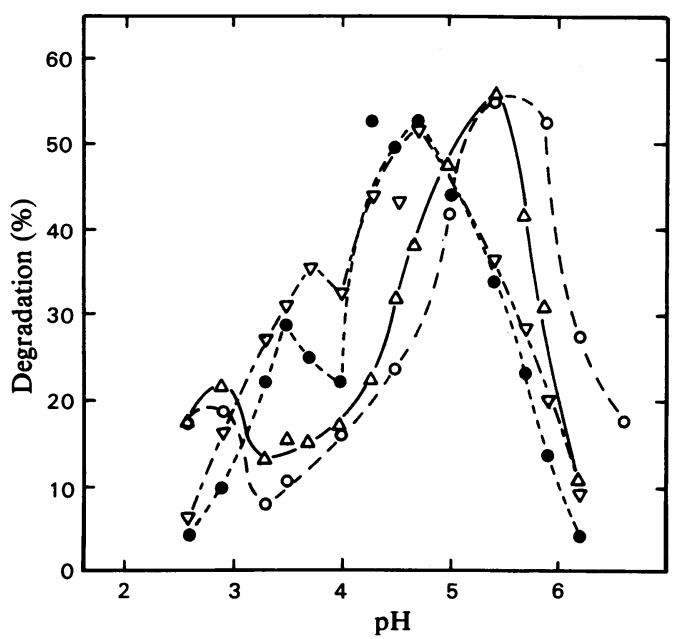

Fig. 4. Effect of pH on the degradation of denatured albumins by rat liver tritosome extract

Conditions were the same as described in the legend to Fig. 3, except that the incubation time was $4 \mathrm{~h}$ for reduced-non-alkylated $(O)$ and for reduced-partially alkylated albumin $(\triangle)$. Incubation time was $2 \mathrm{~h}$ for fully reduced-alkylated $(O)$ and urea-treated $(\nabla)$ albumin. The reaction mixture for urea-treated albumin contained $17 \mu \mathrm{g}$ of tritosome-extract protein rather than $11 \mu \mathrm{g}$.

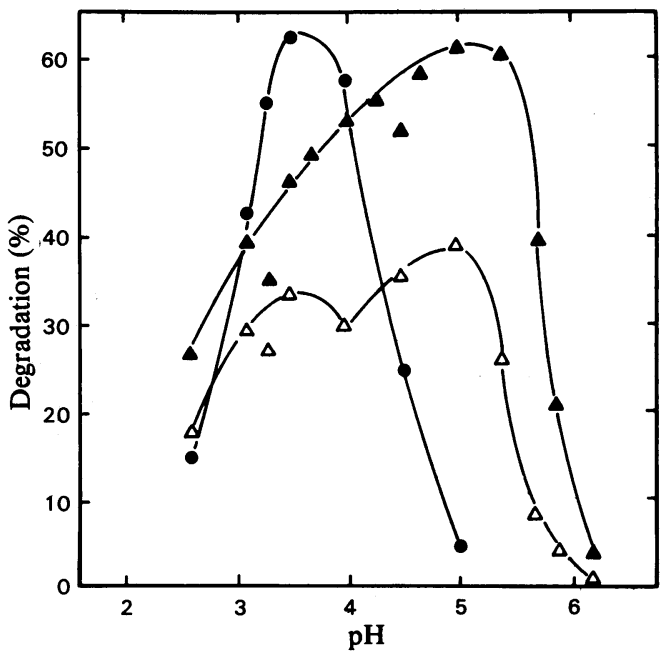

Fig. 5. Effect of $p H$ on the degradation of untreated and totally reduced-alkylated albumin by cathepsin $D$ Reaction conditions were the same as those described in the legend to Fig. 2. Samples were incubated for $2 \mathrm{~h}$ and $4 \mathrm{~h}$ for reduced-alkylated albumin $(\Delta, \Delta)$ and for $4 \mathrm{~h}$ for untreated albumin $(O)$.

optima of these proteins was also shifted to the more alkaline, particularly the reduced-alkylated proteins. These proteins also showed two peaks of activity that were more widely separated in the irreversibly denatured (alkylated) proteins.

Fig. 5 shows $\mathrm{pH} /$ activity curves of degradation of reduced-alkylated and undenatured albumins by cathepsin $D$. The curve for undenatured albumin is almost identical with that shown in Fig. 2. The peak of activity for crystalline cathepsin $D$, however, was somewhat more in the acid range, pH 3.3-3.9. Suggestions of two peaks, similar to the two distinct peaks produced by tritosome extracts, were present in the cathepsin D-catalysed hydrolysis of reduced-alkylated albumin. The $\mathrm{pH}$ optimum was clearly shifted to the right for the reduced-alkylated albumin.

\section{Effects of pepstatin, leupeptin and thiols}

Table 1 shows the stimulatory effects of cysteine and the effects of the proteinase inhibitors pepstatin and leupeptin on hydrolysis of untreated and denatured albumins by tritosome extracts. In the absence of thiol, pepstatin completely inhibited the degradation of all the proteins. The inhibitory effects of pepstatin were decreased in the presence of cysteine, particularly on hydrolysis of formaldehyde-treated albumin to a significantly greater extent than any of the other albumins. These results indicate that cathepsin $\mathrm{D}$ was the most active proteinase in the absence of thiol. This enzyme was also important in the degradation of all albumins in the presence of thiol, but leupeptin-sensitive en- 
zymes played a greater role in the degradation of formaldehyde-treated albumin. A greater involvement of the thiol proteinases in the degradation of formaldehyde-treated albumin is also suggested by the greater degree of stimulation by cysteine shown in Table 1. In agreement with the results shown in Table 1 with respect to inhibitory effects of leupeptin in the absence of cysteine, iodoacetamide ( $2 \mathrm{mM})$ failed to inhibit the degradation of native albumin at pH4. Degradation of fully reducedalkylated albumin was inhibited by $2 \mathrm{mM}$-iodoacetamide by $15-30 \%$ at pH 5.7, but only by $9 \%$ at pH 5 (J. L. Mego, unpublished work).

Raising the $\mathrm{pH}$ from 4 to 5 also produced a significantly greater stimulation by thiol and inhibition by leupeptin of the degradation of untreated albumin (Table 1). Similar results were obtained with reduced-alkylated albumin. Thus the relative importance of cathepsin $\mathrm{D}$ or the thiol proteinases depended on $\mathrm{pH}$ as well as on the substrate and the presence or absence of thiol.

Intralysosomal proteolysis: effects of $\mathrm{pH}$, iodoacetamide and thiols

Table 2 shows the stimulatory effects of thiols and the inhibitory effects of iodoacetamide on proteolysis of denatured albumins in mouse kidney and liver lysosomes. Data from Fig. 1 are also tabulated in Table 2 for comparison. Cysteine as well as GSH was used in the experiments with kidney lysosomes for consistency, since GSH had no effect on liver lysosomes. Many of the denatured albumins tested were not taken up into kidney lysosomes in quantities sufficient to measure proteo-

Table 1. Effects of leupeptin, pepstatin and cysteine on albumin degradation by rat liver tritosome extracts Protein substrates (bovine serum albumin) were labelled with ${ }^{125} \mathrm{I}$ and proteolysis was measured by the conversion of trichloroacetic acid-insoluble into acid-soluble radioactivity during incubation at $37^{\circ} \mathrm{C}$ in $0.25 \mathrm{ml}$ volumes containing $50 \mathrm{~mm}$-Tris/citrate, $0.5 \mathrm{mg}$ of protein substrate and $15 \mu \mathrm{g}$ or $50 \mu \mathrm{g}$ (for formaldehyde-treated albumin) tritosome extract. Incubation times were sufficient to obtain approx. $50 \%$ hydrolysis, usually $2-4 \mathrm{~h}$ depending on the substrate. Results are means \pm S.E.M. of $n$ experiments. Cysteine concentrations were $10 \mathrm{mM}$, pepstatin was $12 \mathrm{mM}$ and leupeptin was $20 \mu \mathrm{M}$.

\begin{tabular}{|c|c|c|c|c|c|c|c|}
\hline \multirow[b]{3}{*}{ Albumin } & \multirow[b]{3}{*}{$\mathrm{pH}$} & & \multirow{3}{*}{$\begin{array}{c}\text { Stimulation } \\
\text { by } \\
\text { cysteine } \\
(\%)\end{array}$} & \multicolumn{4}{|c|}{ Inhibition $(\%)$ by: } \\
\hline & & & & \multicolumn{2}{|c|}{ Pepstatin } & \multicolumn{2}{|c|}{ Leupeptin } \\
\hline & & $n$ & & +Cystine & - Cysteine & +Cysteine & -Cysteine \\
\hline $\begin{array}{l}\text { Untreated } \\
\text { Untreated } \\
\text { Formaldehyde-treated } \\
\text { Reduced-alkylated } \\
\text { Reduced-alkylated } \\
\text { Partially reduced-alkylated } \\
\text { Reduced, not alkylated } \\
\text { Urea-treated }\end{array}$ & $\begin{array}{l}4.0 \\
5.0 \\
5.0 \\
5.0 \\
5.7 \\
5.4 \\
4.7 \\
4.7\end{array}$ & $\begin{array}{l}4 \\
5 \\
5 \\
6 \\
4 \\
4 \\
1 \\
4\end{array}$ & $\begin{array}{c}26 \pm 6 \\
44 \pm 6 \\
960 \pm 23 \\
44 \pm 6 \\
140 \pm 6 \\
116 \pm 13 \\
122 \\
392 \pm 77\end{array}$ & $\begin{array}{l}83 \pm 4 \\
70 \pm 5 \\
58 \pm 6 \\
82 \pm 5 \\
99 \pm 0.4 \\
84 \pm 1 \\
92 \\
19 \pm 1\end{array}$ & $\begin{array}{l}100 \\
98 \pm 2 \\
94 \pm 4 \\
100 \\
100 \\
99 \pm 0.5 \\
98 \\
97 \pm 1\end{array}$ & $\begin{array}{l}12 \pm 5 \\
42 \pm 7 \\
80 \pm 3 \\
25 \pm 3 \\
57 \pm 3 \\
43 \pm 2 \\
46 \\
51 \pm 9\end{array}$ & $\begin{array}{r}3 \pm 1 \\
10 \pm 7 \\
12 \pm 8 \\
7 \pm 1 \\
20 \pm 4 \\
15 \pm 5 \\
57 \\
24 \pm 4\end{array}$ \\
\hline
\end{tabular}

Table 2. Stimulation by thiols and inhibition by iodoacetamide of albumin degradation in mouse kidney and liver lysosomes Subcellular particulate suspensions containing lysosomes filled with injected ${ }^{125}$ I-labelled protein were incubated at $37^{\circ} \mathrm{C}$ in media with and without thiol or iodoacetamide and other additions as described in the Experimental section. Thiols were not added to samples containing iodoacetamide. Percentage inhibition or stimulation was calculated from the fraction of the total radioactivity converted into trichloroacetic acid-soluble form during $60 \mathrm{~min}$ incubation. The total acid-precipitable radioactivity converted into acid-soluble form during $60 \mathrm{~min}$ incubation was approx. $20-30 \%$ in liver suspensions and about $14-25 \%$ in kidney suspensions. Results are means \pm S.E.M. for the numbers of experiments shown in parentheses.

\begin{tabular}{|c|c|c|c|c|}
\hline \multicolumn{3}{|c|}{ Stimulation by thiol (\%) } & & \\
\hline \multicolumn{2}{|c|}{ Kịdney } & \multirow{3}{*}{$\begin{array}{c}\text { Liver } \\
10 \mathrm{mM}- \\
\text { Cysteine }\end{array}$} & \multirow{2}{*}{\multicolumn{2}{|c|}{$\begin{array}{c}\text { Inhibition by } \\
\text { iodoacetamide (\%) }\end{array}$}} \\
\hline \multirow{2}{*}{$\begin{array}{l}2 \mathrm{mM}- \\
\text { GSH }\end{array}$} & \multirow{2}{*}{$\begin{array}{l}10 \mathrm{~mm}- \\
\text { Cysteine }\end{array}$} & & & \\
\hline & & & Kidney & Liver \\
\hline $\begin{aligned} 74 & \pm 13(7) \\
6 & \pm 7(6)\end{aligned}$ & $\begin{array}{r}69 \pm 10(9) \\
9 \pm 10(8)\end{array}$ & $\begin{array}{r}58 \pm 4(6) \\
-11 \pm 3(8)\end{array}$ & $\begin{array}{l}78 \pm 4(5) \\
33 \pm 6(8)\end{array}$ & $\begin{array}{l}89 \pm 1(7) \\
48 \pm 3(8)\end{array}$ \\
\hline- & $6 \pm 10(11)$ & $24 \pm 4(10)$ & $46 \pm 8(11)$ & $36 \pm 3(10)$ \\
\hline- & - & $49 \pm 3(6)$ & - & $59 \pm 3(6)$ \\
\hline - & - & $31 \pm 3(9)$ & - & $59 \pm 2(9)$ \\
\hline
\end{tabular}




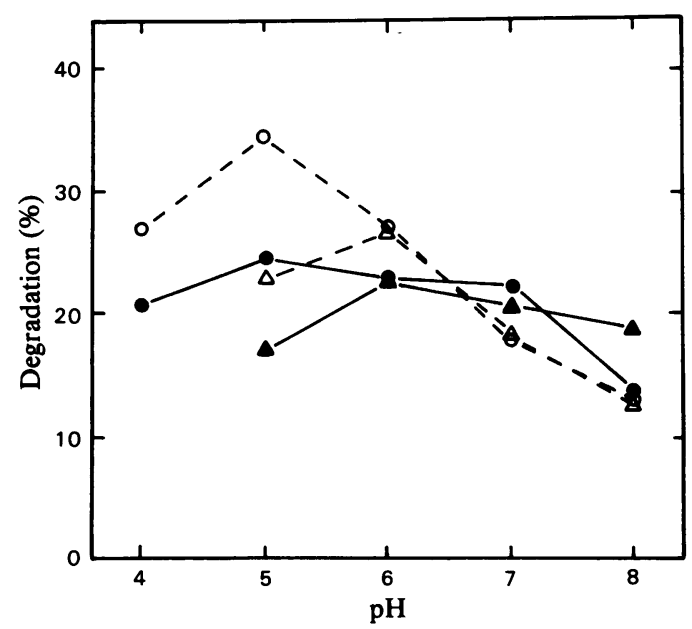

Fig. 6. Effect of $\mathrm{pH}$ on the catabolism of formaldehydetreated and reduced-alkylated serum albumins in mouse kidney and liver lysosomes

Lysosomes filled with ${ }^{125} \mathrm{I}$-labelled formaldehydetreated or reduced-alkylated albumin were centrifuged from tissue homogenates and incubated in media containing $0.25 \mathrm{M}$-sucrose, $5 \mathrm{mM}-\mathrm{MgCl}_{2}$, $10 \mathrm{~mm}$-cysteine and $50 \mathrm{~mm}$-Tris/acetate buffers. Intralysosomal proteolysis was assayed by analysis of trichloroacetic acid-soluble radioactivity produced during $60 \mathrm{~min}$ incubation at $37^{\circ} \mathrm{C}$. Liver lysosomes: 0 , formaldehyde-treated albumin; $\boldsymbol{\Delta}$, reduced-alkylated albumin. Kidney lysosomes: $\bigcirc$, formaldehyde-treated albumin; $\Delta$, reduced-alkylated albumin.

lysis, and others were taken up very poorly. Thus data on effects of cysteine and iodoacetamide were more reliable in liver lysosomes. These experiments were also performed in the presence of ATP, which has been shown to stimulate intralysosomal proteolysis in neutral or alkaline media (Mego et al., 1972; Mego, 1975) with little or no difference in the results.

The $\mathrm{pH}$ optima for formaldehyde-treated and reduced-alkylated albumin degradation were about 5.2 and 5.8 respectively (Figs. 2 and 3). Fig. 6 shows the $\mathrm{pH} /$ activity curves for intralysosomal proteolysis of these proteins in mouse liver and kidney lysosomes. The $\mathrm{pH}$ optimum for hydrolysis of formaldehyde-treated albumin was clearly about 5 , and that for reduced-alkylated albumin was in the vicinity of 6 . These results provide further evidence that the properties of proteolysis by tritosome extracts were similar to those in liver and kidney lysosomes.

\section{Discussion}

Serum albumin consists of a single polypeptide chain with 17 disulphide bonds (Brown, 1974,
1975). Degradation of this protein by cathepsin D is stimulated by thiols such as GSH (Kooistra et al., 1982). However, if the disulphides of albumin were reduced with dithiothreitol and alkylated to prevent reoxidation, GSH or cysteine had no effect. These results and the work of Libenson \& Jena $(1963,1964)$ establish that GSH and other thiols facilitate proteolysis by reducing the disulphide bonds of protein substrates.

Proteolysis in liver lysosomes was not stimulated by GSH in the particulate system described in the present studies. The reason for this is not clear, but the most likely explanation is that the tripeptide did not penetrate the liver lysosome membrane. Cysteine is an effective stimulator of albumin degradation in these lysosomes (Mego \& McQueen, 1965; Mego, 1973; see also Fig. 1). Intracellular concentrations of this amino acid, however, are in the range $10-100 \mu \mathrm{M}$, compared with $0.5-10 \mathrm{mM}$ for glutathione (Meister \& Tate, 1976; Cooper, 1983). Proteolysis of formaldehyde-treated albumin was sensitive to GSH concentrations as low as $50 \mu \mathrm{M}$ (not shown in Fig. 1) in mouse kidney lysosomes, and cysteine had no effect at this concentration. Thus GSH, a much larger molecule than cysteine, was a more effective stimulator of intralysosomal proteolysis. GSH and cysteine were equally effective in membrane-free systems catalysed by tritosome extracts (J. L. Mego, unpublished work). Neither cysteine nor GSH had significant effects on proteolysis in kidney lysosomes if the substrate contained no disulphide bonds (reduced-alkylated albumin). These observations suggest that a system may exist to facilitate entry of the tripeptide into kidney lysosomes.

In general, results obtained on the effects of thiols and iodoacetamide on intralysosomal proteolysis (Table 2) correlated well with those obtained with rat liver tritosome extracts. Intralysosomal degradation of formaldehyde-treated albumin was most highly stimulated by thiols and inhibited by iodoacetamide in both liver and kidney lysosomes, suggesting that thiol proteinases were more important. Degradation of formaldehyde-denatured albumin was also maximally stimulated by thiols in tritosome extracts, and little activity was noted in their absence. Barrett (1973) has shown that purified cathepsin $B_{1}$ is inactive in the absence of thiols after storage. Degradation of formaldehyde-denatured albumin by tritosome extracts was also inhibited more by leupeptin than by pepstatin, suggesting a greater involvement of thiol proteinases. The degradation of albumins with completely reduced-alkylated disulphides was not significantly stimulated by thiols in lysosomes, but some stimulation occurred if albumin was only partially reduced, reduced but not alkylated or urea-treated. Thus some intact disulphide 
bonds appeared to be necessary in protein substrates to elicit a stimulatory effect by thiols on intralysosomal proteolysis. This suggests that thiols function to facilitate proteolysis in lysosomes by reducing disulphide bonds of protein substrates. Inhibitory effects of iodoacetamide on proteolysis in lysosomes suggested a greater involvement of cathepsin D in the degradation of reduced or ureatreated albumins. These results also correlated well with the inhibitory effects of pepstatin on the degradation of reduced-alkylated, reduced-nonalkylated, or urea-treated albumins by tritosome extracts, which suggested that cathepsin $D$ was involved.

Although the results described in the present studies suggest that thiols facilitated intralysosomal proteolysis by reducing disulphide bonds, there is a good possibility that these disulphides are not reduced in vivo in all lysosomes. Cystine is known to accumulate in fibroblast or leucocyte lysosomes from cystinotic patients (Schulman et al., 1969), and evidence has been presented that the amino acid arises from intralysosomal proteolysis (Thoene et al., 1977; Thoene \& Lemons, 1982). Thoene et al. (1976) have proposed that the physiological disulphide reductant may be cysteamine, on the basis of the observation that this substance facilitates removal of accumulated cystine from cystinotic cells by reduction to cysteine. Kooistra et al. (1982) have added further support for this hypothesis by providing evidence that both cysteamine and its oxidized product cystamine are permeant to the lysosome membrane. However, the defect in cystinosis appears to be impairment of cystine transport from lysosomes (Gahl et al., 1982; Jonas et al., 1982; Steinherz et al., 1982) which suggests that protein disulphide bonds or cystine products of proteolysis are not reduced in these lysosomes. Thus GSH may be the physiological protein disulphide-bond reductant in certain lysosomes (e.g. kidney), but not in others. Another type of lysosome in which proteolysis is stimulated by GSH is the thyroid lysosome (Pisarev \& Dumont, 1975; Peake et al., 1967). However, a significant fraction of lysosomes sedimented from rat thyroid homogenates appears to be permeable to relatively large molecules such as leupeptin, p-nitrophenyl phosphate or $\mathrm{ZnSO}_{4}$ (Fouchier et al., 1981, 1983a). GSH may stimulate proteolysis by entry through tears in these damaged lysosomes.

A variety of experimental evidence has been reported in the present studies that cathepsin $D$ is the major proteinase involved in the catabolism of serum albumin, except formaldehyde-treated albumin, by lysosomal enzymes. For example, the $\mathrm{pH} /$ activity curves for the catabolism of native serum albumin catalysed by crystalline cathepsin
D or tritosome extracts, the inhibitory effects of pepstatin, leupeptin and iodoacetamide on proteolysis catalysed by tritosome extracts, and the effects of iodoacetamide and the $\mathrm{pH}$ curves for the catabolism of reduced-alkylated albumin in lysosomes, are consistent with this hypothesis. These results are not in agreement with the work of Huisman et al. (1974), who found no inhibitory effects of pepstatin on the degradation of native bovine serum albumin by a rat liver tritosome extract at pH 5 in the presence of $2 \mathrm{~mm}$-dithiothreitol. Under these conditions, however, leupeptin inhibited proteolysis by approx. $50 \%$, a result in agreement with the data reported in the present studies. The reason for the discrepancy of the results with pepstatin is not clear.

The $\mathrm{pH}$ within rat liver lysosomes has been estimated to be about 5 (Reijngoud \& Tager, 1973; Hollemans et al., 1979; Ohkuma et al., 1982), and in macrophages it is 4.7-4.8 and may fall to as low as 4.5 (Ohkuma \& Poole, 1978). The $\mathrm{pH}$ optimum for degradation of crystalline bovine serum albumin by cathepsin D was approx. 3.0-4.4 (Fig. 5). Ferenčik \& Štefanovič (1974), using human serum albumin, reported a peak at $\mathrm{pH} 3.0-3.5$ for purified chicken spleen cathepsin D. At pH5, the rate of albumin hydrolysis by tritosome extracts was approx. $20 \%$ of that at the pH optimum (Fig. 2). These preparations of albumin undoubtedly contained some denatured protein, which may have accounted for the activity at $\mathrm{pH} 5$, since denaturation shifted the pH optimum to 4.5-5.9. It is possible, therefore, that little or no degradation of native albumin by lysosomal proteinases occurs at pH5. Half-lives of serum albumin in the blood streams of a variety of animals have been measured (Gitlin et al., 1951; Goldsworthy \& Volwiler, 1957; McFarlane, 1957), but little is known about the mechanisms involved in albumin degradation. Since there appear to be no binding sites for albumin uptake in the liver (Stremmel et al., 1983), albumin turnover may be accomplished by pinocytosis. Normal albumin would not be degraded after fusion of pinocytosis vesicles with lysosomes, but any denatured molecules would be attacked. Undegraded albumins may then be recycled to the blood stream by exocytosis. This system may function as a sieving or screening process for serum albumin turnover.

\section{References}

Barrett, A. J. (1973) Biochem. J. 131, 809-822

Barrett, A. J., Kregar, I., Turk, V. \& Woessner, J. F., Jr. (1977) in Intracellular Protein Catabolism II (Turk, V. \& Marks, N., eds.), pp. 353-356, Plenum Press, New York and London

Bertini, F., Bari, D. R. \& Mazzei, H. (1972) J. Cell. Physiol. 80, 63-72 
Brown, J. R. (1974) Fed. Proc. Fed. Am. Soc. Exp. Biol. 33, 1389

Brown, J. R. (1975) Fed. Proc. Fed. Am. Soc. Exp. Biol. 34, 591

Cooper, A. J. L. (1983) Annu. Rev. Biochem. 52, 187222

Cunningham, M. \& Tang, J. (1976) J. Biol. Chem. 251, 4528-4536

Davies, M., Lloyd, J. B. \& Beck, F. (1971) Biochem. J. 121, 21-26

Dean, R. T. (1977) in Lysosomes, A Laboratory Handbook (Dingle, J. T., ed.), 2nd edn., pp. 1-16, North-Holland Publishing Co., Amsterdam, New York and Oxford

Ducastaing, A., Azanza, J.-L., Raymond, J., Robin, J.-M. \& Creac'h, P. (1976) Biochimie 58, 783-791

Ferenčik, M. \& Štefanovič, J. (1974) Biologia (Bratislava) 29, 453-463

Fouchier, F., Mego, J. L., Dang, J. \& Simon, C. (1981) Ann. Endocrinol. 42, 78a

Fouchier, F., Mego, J. L., Dang, J. \& Simon, C. (1983a) Ann. Endocrinol. 103, 53-61

Fouchier, F., Mego, J. L., Dang, J. \& Simon, C. (1983b) Ann. Endocrinol. 103, 62-67

Gahl, W. A., Tietze, F., Basham, N., Steinherz, R. \& Schulman, J. D. (1982) J. Biol. Chem. 257, 95709575

Gitlin, D., Latta, H., Batchelor, W. H. \& Janeway, C. A. (1951) J. Immunol. 66, 451-461

Goldsworthy, P. D. \& Volwiler, W. (1957) Ann. N.Y. Acad. Sci. 70, 26-48

Griffiths, P. A. \& Lloyd, J. B. (1979) Biochem. Biophys. Res. Commun. 89, 428-434

Hollemans, M., Reijngoud, D. J. \& Tager, J. M. (1979) Biochim. Biophys. Acta 551, 55-66

Huisman, W., Lanting, L., Doddema, H. J., Bouma, J. M. W. \& Gruber, M. (1974) Biochim. Biophys. Acta 370, 297-307

Jonas, A. J., Greene, A. A., Smith, M. L. \& Schneider, J. A. (1982) Proc. Natl. Acad. Sci. U.S.A. 79, 44424445

Kirschke, H., Langner, J., Wiederanders, B., Ansorge, S., Bohley, P. \& Broghammer, V. (1976) Acta Biol. Med. Germ. 35, 285-299

Kirsche, H., Langner, J., Wiederanders, B., Ansorge, S. \& Bohley, P. (1977) Eur. J. Biochem. 74, 293-301

Kooistra, T., Millard, P. C. \& Lloyd, J. B. (1982) Biochem. J. 204, 471-477

Leighton, F., Poole, B., Beaufay, H., Baudhuin, P., Coffey, J. W., Fowler, S. \& de Duve, C. (1968) J. Cell Biol. 37, 483-513

Libenson, L. \& Jena, M. (1963) Arch. Biochem. Biophys. 100, $441-450$

Libenson, L. \& Jena, M. (1964) Arch. Biochem. Biophys. 104, 292-296
Lowry, O. H., Rosebrough, N. J., Farr, A. L. \& Randall, R. J. (1951) J. Biol. Chem. 193, 265-275

Marzella, L. \& Glaumann, H. (1980) Virchows Arch. B 34, 111-122

McFarlane, A. S. (1957) Ann. N.Y. Acad. Sci. 70, 19-25

Mego, J. L. (1971) Biochem. J. 122, 445-452

Mego, J. L. (1973) in Lysosomes in Biology and Pathology (Dingle, J. T., ed.), vol. 3, pp. 527-537, North-Holland Publishing Co., Amsterdam and London

Mego, J. L. (1975) Biochem. Biophys. Res. Commun. 67, 572-575

Mego, J. L. \& McQueen, J. D. (1965) Biochim. Biophys. Acta 100, 136-143

Mego, J. L., Farb, R. M. \& Barnes, J. (1972) Biochem. J. 128, 763-770

Meister, A. \& Tate, S. S. (1976) Annu. Rev. Biochem. 45, 559-604

Nilsson, M. \& Berg, T. (1977) Biochim. Biophys. Acta 497, 171-182

Ohkuma, S. \& Poole, B. (1978) Proc. Natl. Acad. Sci. U.S.A. 75, 3327-3331

Ohkuma, S., Moriyama, Y. \& Takano, T. (1982) Proc. Natl. Acad. Sci. U.S.A. 79, 2758-2762

Peake, R. G., Balasubramanian, K. L. \& Diess, W. P., Jr. (1967) Biochim. Biophys. Acta 148, 689-702

Pisarev, N. A. \& Dumont, J. E. (1975) Acta Endocrinol. (Copenhagen) 79, 76-85

Putnam, F. W. (1965) in The Proteins: Composition, Structure and Function (Neurath, H., ed.), vol. 3, pp. 187-199, Academic Press, New York and London

Reijngoud, D. J. \& Tager, J. M. (1973) Biochim. Biophys. Acta 297, 174-178

Schulman, J. D., Bradley, K. H. \& Seegmiller, J. E. (1969) Science 166, 1152-1154

Steinherz, R., Tietze, F., Gahl, W. A., Triche, T. J., Chiang, H., Modesti, A. \& Schulman, J. D. (1982) Proc. Natl. Acad. Sci. U.S.A. 79, 4446-4450

Stremmel, W., Potter, B. J. \& Berk, P. D. (1983) Biochim. Biophys. Acta 756, 20-27

Thoene, J. G. \& Lemons, R. M. (1982) Biochem. J. 208, 823-830

Thoene, J. G., Oshima, R. G., Crowhall, J. C., Olson, D. L. \& Schneider, J. A. (1976) J. Clin. Invest. 58, 180 189

Thoene, J. G., Oshima, R. G., Ritchie, D. G. \& Schneider, J. A. (1977) Proc. Natl. Acad. Sci. U.S.A. 74, 4505-4507

Van Herle, A. J., Vassart, G. \& Dumont, J. E. (1979) $N$. Engl. J. Med. 301, 239-249

Woessner, J. F., Jr. (1973) J. Biol. Chem. 248, 1634-1642

Wollman, S. H. (1969) in Lysosomes in Biology and Path'ology (Dingle, J. T. \& Fell, H. B., eds.), vol. 2, pp. 483513, North-Holland Publishing Co., Amsterdam and London 